\title{
Vascular Plug Embolization for the Treatment of Intralober Pulmonary Sequestration
}

Murat Muhtar Yılmazer (1) Timur Meşe (D) Rahmi Özdemir (1)

\section{intralober Pulmoner Sekestrasyon Tedavisinde Vasküler Tıkaç Embolizasyonu}

A 6-month-old girl was admitted to our hospital for inadequate weight gain and a systolic murmur detected during physical examination. A grade $1 / 6$ systolic murmur best heard at the right second intercostal space was detected. She was weighing $6.5 \mathrm{~kg}$ (10-25 p). Other system examinations were normal. Lower extremity pulses were felt. Echocardiography revealed increased peak instantaneous gradient $(20 \mathrm{mmHg})$ in the descending aorta. However, there was no evidence of obstruction by 2-dimensional echocardiography. We decided to perform conventional

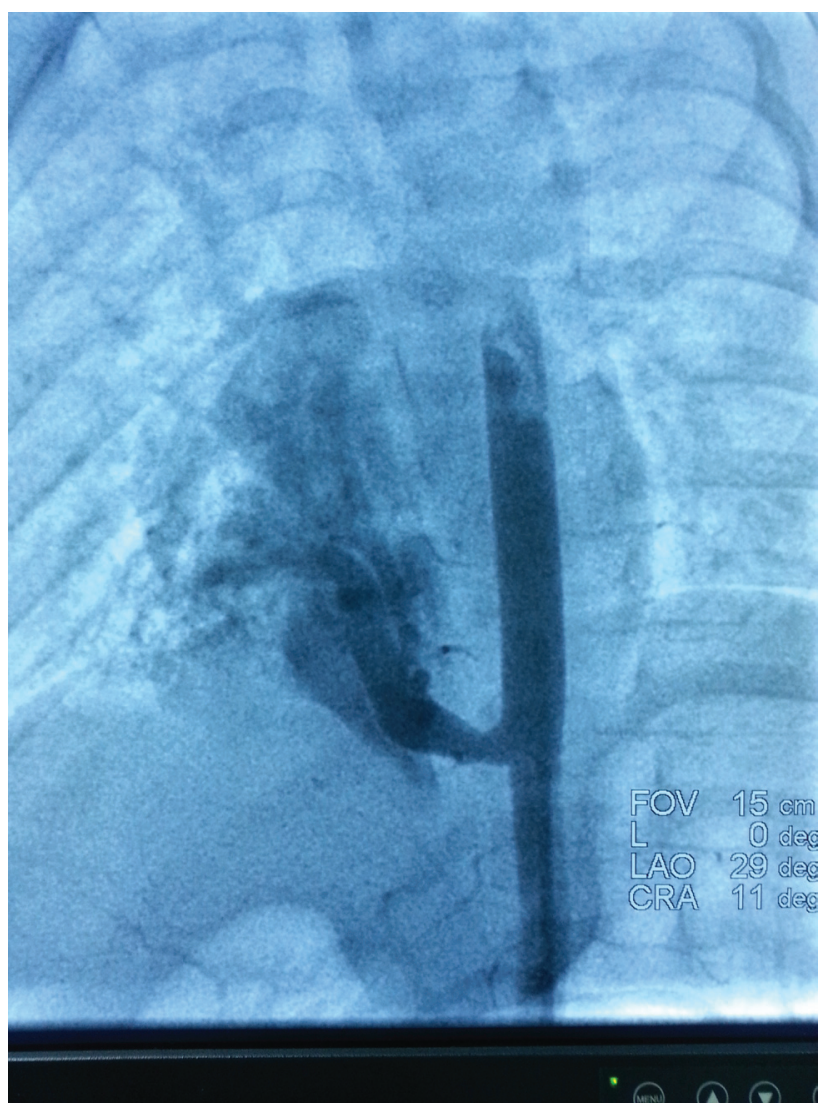

Figure 1. Demonstrating a large feeding artery orginating from the abdominal aorta and fed to intralober pulmonary sequestration. angiography to exclude coarctation. However, coarctation was not revealed on angiography. Surprisingly a large feeding artery originating from the abdominal aorta and supplying intralober pulmonary sequestration was detected (Figure 1). An intralober PS was drained by the right inferior pulmonary vein. The feeding artery branched $13 \mathrm{~mm}$ distal to its aortic insertion and the diameter of this artery initial branching was $6 \mathrm{~mm}$. We discussed the patient with cardiovascular surgeons and transcatheter closure of the feeding artery was suggested as the final decision. Coils usually

(c) Telif hakkı İzmir Dr. Behçet Uz Çocuk Hastalıkları ve Cerrahisi Eğitim ve Araştırma Hastanesi'ne aittir. Logos Tıp Yayıncılık tarafindan yayınlanmaktadır. Bu dergide yayınlanan bütün makaleler Creative Commons Atff-GayriTicari 4.0 Uluslararası Lisansı ile lisanslanmıștr. 


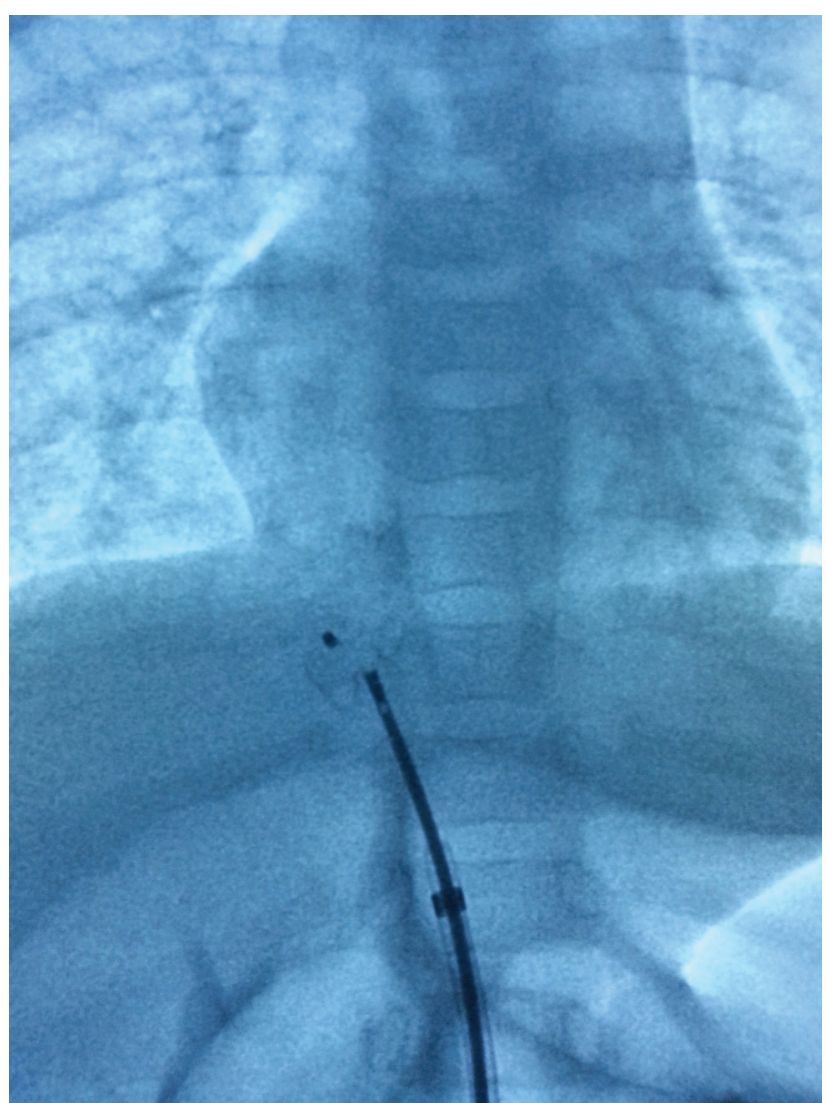

Figure 2. Vasular plug placed before the branching into the feeding artery.

were used for occlusion of the branches of feeding artery in previous reports. But we decided to use a vascular plug for occlusion of the main feeding artery proximal to its branching site. Two $\mathrm{mm}$ larger device (8mm CERATM vascular plug) was chosen and the plug was inserted into the feeding artery proximal to its branching (Figure 2). The procedure was performed without complications, and the feeding artery was completely occluded (Figure 3). The infant's body weight had increased and she had no respiratory problems or signs of heart failure during the follow-up of 8 months. Coil embolization of the fee-

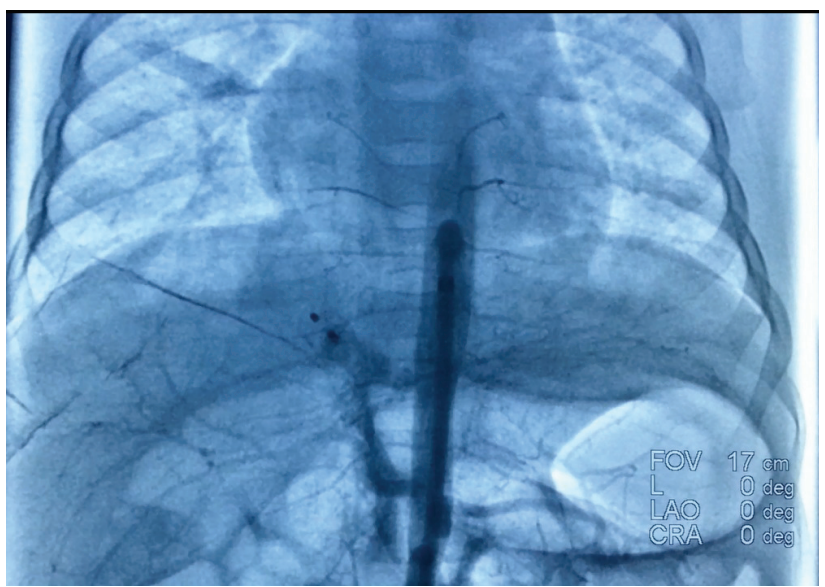

Figure 3. Image showing the completely occluded feeding artery with vascular plug.

ding artery is reported as an alternative method for the treatment of extralobar and intralobar PS (1). However residual leakage remains a high probability for the coil occlusion. Vascular plug is a selfexpandable device that effectively, and completely occludes large vessels with high flow ${ }^{(2,3)}$. Vascular plug occlusion is a safe alternative method compared to surgery and to other embolization agents used in infants with PS.

\section{REFERENCES}

1. Ganeshan A, Freedman J, Hoey ET, Steyn R, Henderson J, Crowe PM. Transcatheter coil embolisation: a novel definitive treatment option for intralobar pulmonary sequestration. Heart Lung Circ. 2010;19:561-5. https://doi.org/10.1016/j.hlc.2010.05.008

2. Herbert CE, Reddy SR, Lemler MS. Use of Amplatzer Vascular Plugs for the treatment of combined extralobar and intralobar pulmonary sequestration in a 5-year-old child. Cardiol Young. 2016;26:1441-4. https://doi.org/10.1017/S1047951116000901

3. Berthod PE, Chevallier O, Pottecher P, Gehin S, Sapin E, Loffroy R. Transcatheter embolization of a large aberrant systemic artery to an intralobar pulmonary sequestration using an Amplatzer vascular plug in an adolescent. Quant Imaging Med Surg. 2017;7:152-5.

https://doi.org/10.21037/qims.2016.11.04 